\title{
A legal approach to tackling contract cheating?
}

\author{
Michael J. Draper ${ }^{1}$ and Philip M. Newton ${ }^{2^{*}}$ (D)
}

\author{
* Correspondence: \\ p.newton@swansea.ac.uk \\ ${ }^{2}$ Swansea University Medical School, \\ Swansea University, Singleton Park \\ Campus, Swansea, UK \\ Full list of author information is \\ available at the end of the article
}

\begin{abstract}
The phenomenon of contract cheating presents, potentially, a serious threat to the quality and standards of Higher Education around the world. There have been suggestions, cited below, to tackle the problem using legal means, but we find that current laws are not fit for this purpose. In this article we present a proposal for a specific new law to target contract cheating, which could be enacted in most jurisdictions.

We test our proposed new law against a number of issues that would need to be considered before any legal approach could be successful; would changing the legal status of contract cheating make it less likely to happen? Could this be achieved in a specific way? If so, who should actually be prosecuted and what offence are they committing? Would it actually address the causes of contract cheating? We suggest some answers to these questions, but then also identify a number of unintended potential consequences. We therefore additionally consider whether a legal approach is possible or even desirable.

We conclude that a legal approach to contract cheating is possible, and, on balance, appropriate. Using UK law as an example, we offer a specific suggestion to lawmakers, around the world, for how this might be achieved, and conclude that the most successful approach would be to focus largely on a law targeting the providers of contract cheating, in particular commercial services.
\end{abstract}

\section{Introduction}

Contract cheating, as we define here, is a basic relationship between three actors; a student, their university, and a third party who completes assessments for the former to be submitted to the latter, but whose input is not permitted. 'Completes' in this case means that the third party makes a contribution to the work of the student, such that there is reasonable doubt as to whose work the assessment represents.

Media portrayals often feature commercial companies as the third party (Andrew Bomford 2016; Usborne 2017; Henry, Flyn, and Glass 2014; Bartlett 2009), although the principle can also apply where the third party is an individual, including a friend or family member, offering their services for commercial or any other benefit. Media portrayals also often refer to the 'essay' as the assignment being purchased, but in reality it applies to any sort of assignment; commercial services exist to write PhDs, or to sit exams on behalf of students. This relationship, and consideration of its legal status, has been around for some considerable time for example in the form of 'term paper

(c) The Author(s). 2017 Open Access This article is distributed under the terms of the Creative Commons Attribution 4.0 International License (http://creativecommons.org/licenses/by/4.0/), which permits unrestricted use, distribution, and reproduction in any medium, provided you give appropriate credit to the original author(s) and the source, provide a link to the Creative Commons license, and indicate if changes were made. 
mills' that sold papers, pre-and custom-written, on university campuses in the 1970s (Duke Law Journal 1974).

There are a number of additional actors potentially involved, directly or indirectly, knowingly or unknowingly, in the process of contract cheating, all of whom may be affected by some form of legal approach. These are summarised in Fig. 1.

\section{Structure and principles of this paper}

We begin by introducing the current legal status of contract cheating, and demonstrate how the current legal position is not suitable to tackle contract cheating. Based upon this background research, we make a proposal for a specific new law to tackle contract cheating (Table 1). We then test this law against various issues which have dogged previous attempts to tackle contract cheating through legal means.

Throughout, we introduce some very basic legal principles. Since many readers of the International Journal of Educational Integrity are unlikely to have formal legal training, where these basic principles are introduced we identify them with the tag 'Legal Basics'.

\section{The current legal position and its limitations}

Legal Basics; Criminal vs Civil Law. In general, criminal law exists to protect society and social order, and prosecutions under the criminal law are generally brought by the state (e.g. murder, fraud, theft). Civil law actions are normally bought by private individuals or parties against each other and usually seek to redress some form of loss. The focus of this paper is on criminal law, as it serves the interests and needs of society as a whole. In countries such as the UK, Australia, New Zealand, Canada and the US, two criteria must usually be satisfied in order to pursue any criminal prosecution; (1) there must be evidence that the offence has actually occurred and (2) it must be in the public interest to pursue a prosecution. ${ }^{1}$

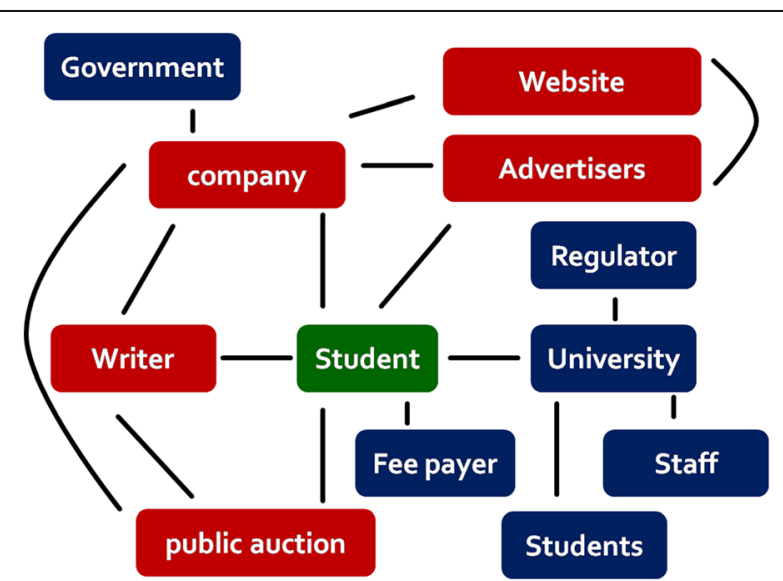

Fig. 1 Stakeholders in contract cheating. At the heart of the identified relationships is a student (green) whose arrangements with others are agreements governed primarily (but not exclusively) by the (civil) law of contract. Each of the parties involved may be affected, in some way, by the enacting of a legal approach to contract cheating. Not every party is involved in every incidence of contract cheating or would be affected by every type of legal approach. Red indicates stakeholders whose actions could be interpreted as a criminal offence under the new law proposed in Table 1. Government - Obviously many parties shown are also regulated by government but we show this specific relationship to indicate the perceived status of some contract cheating service providers as legitimate businesses operating in a commercial environment. University - in reality this could be any provider of education 
Table 1 Proposal for a new "offence to provide or advertise cheating services"

(1) A person commits an offence if the person provides any service specified in subsection (4) but in the case of a service being provided in part then a person commits an offence only if the assignment or work could not otherwise be reasonably considered to be that of the student concerned

(2) A person commits an offence if the person advertises any services specified in subsection (4)

(3) A person commits an offence who, without reasonable excuse, publishes an advertisement for any service specified in subsection (4).

(4) The services referred to in subsections (1) to (3) are-

a. completing in whole or in part an assignment ${ }^{\mathrm{a}}$ or any other work that a student enrolled at a Higher Education provider is required to complete as part of a Higher Education course in their stead without authorisation from those making the requirement;

b. providing or arranging the provision of an assignment ${ }^{\mathrm{a}}$ or any other work (in whole or in part) that a student enrolled at a Higher Education provider is required to complete as part of a Higher Education course in their stead without authorisation from those making the requirement;

(5) A person shall not be guilty of an offence in subsections (1) (2) and (3) above if he or she demonstrates that they did not know and could not with reasonable diligence have ascertained that the services might or would be used for the purposes specified in subsection (4)

(6) Where a body corporate is guilty of an offence under this section and the offence is committed with the consent or connivance of, or to be attributable to neglect on the part of, a director, manager, secretary or other similar officer of the body corporate, or a person who was purporting to act in any such capacity, he or she, as well as the body corporate, is guilty of that offence.

Using 'strict liability' removes the need to show intent on behalf of the provider of contract cheating services. The offence could be added to existing legislation (e.g fraud, or education laws) or could stand alone. It would apply to individuals as well as companies; a friend or family member who completes an assignment for a student would be committing an offence. ${ }^{a}$ Would apply to examinations as well as coursework, thus covering exam impersonation (although a separate specific offence to this effect could be included to put the matter beyond doubt). The proposal would specifically target those stakeholders shown in red in Table 1

In the case of contract cheating, evidence is often available, and it would seem reasonable to conclude that it is in the public interest to intervene to address situations where (for example) practising healthcare professionals, engineers, lawyers or others have paid others to complete assessments for them, rather than personally completing the work required to obtain a qualification.

Although the process of contract cheating includes many actors and legal relationships, most of the literature regarding the legal position has focused on the companies and others who offer contract cheating services. This has been reviewed a number of times recently (Newton and Lang 2016; Dickerson 2007; Owings and Nelson 2014) although as identified above there have been legal considerations of contract cheating since at least the 1970s. The findings from these reviews are neatly summarised in the title of the Dickerson review; "Facilitated Plagiarism: The Saga of Term-Paper Mills and the Failure of Legislation and Litigation to Control Them". In essence; some countries/ states have laws designed to prevent the activities of contract cheating services, but they have not been very effective.

One route has been to target the advertising of contract cheating. A voluntary ban was imposed by Google as far back as $2007^{2}$ and yet paid-for advertising is still clearly visible following a relevant search. We recently reviewed the advertising and terms and conditions for UK-registered commercial essay-writing services. We found that all the companies we reviewed offered some form of 'plagiarism-free guarantee' for the work they produce (Draper, Ibezim and Newton 2017). A typical site will also offer customers the opportunity to specify the grade they want, the referencing convention to be used, a range of delivery dates, the possibility of draft versions, and so on. In our academic opinion, the average person would reasonably conclude, on the basis of the advertising used, that these services are setting out to help students cheat. Targeting contract 
cheating through advertising is unlikely to be as effective as a specific law against the provision of contract cheating services.

However, an example of the difficulties posed by a the introduction of specific laws designed to tackle contract cheating is the position in New Zealand, where a law, introduced In 2011 makes it an offence to provide or advertise cheating services (Education Act 1989, s 292E). Cheating services include completing or the provision of any assignment or any other work that any student is required to complete. A person who commits an offence under s 292E is liable on summary conviction to a fine not exceeding $\$ 10,000$. However to our knowledge the law has only been deployed once, in $2014,{ }^{3}$ and the case was not pursued to completion. The court was satisfied that the requisite level of criminality had been made out with respect to $292 \mathrm{E}$, and issued a confiscation order to seize property of a 'contract cheating company' for the purposes of further investigation, but the case was not pursued beyond this point as the confiscation order was an acceptable level of closure.

An additional consideration with the New Zealand law is the penalty; a maximum of 10,000 NZD (approx 6500 Euro, 7250 USD, 5670 GBP, 9500 AUD, figures accurate June 2017). During the aforementioned case it was revealed that the defendant's company, Assignments4U, had received over 1.1million NZD in payments over 5 years. Unless the penalty is sufficiently proportionate, it will not be effective; a small fine may simply be seen as a running cost for a large company.

The current law enacted in New Zealand was the basis of an unsuccessful proposal to amend UK law early in 2017 (Newton and Draper 2017a) and is the basis for a similar proposal in Ireland (Irish Legal News 2017). The failure of the UK amendment to pass was due to two basic concerns, which also apply to the New Zealand law, and from which we can learn from as we consider further legal approaches; 'intent' and a failure to specifically define 'contract cheating'.

Legal Basics; the problem of 'intent'. Often a thorny question in legal situations; what did a defendant know about the consequences of their actions. Intent, or 'mens rea', in criminal law is concerned with the state of mind of the defendant. Crimes usually require proof of mens rea (unless an offence of strict liability as we discuss below). There are three principal types of mens rea: intention, recklessness and negligence. Companies are legal persons and may therefore be criminally responsible for offences requiring intent (mens rea), although case law ${ }^{4}$ restricts the application of this principle to the Board of Directors, the managing director and perhaps other superior officers who carry out functions of management. ${ }^{5}$

The current New Zealand law referenced above, which is aimed at those who provide contract cheating services to students states that "A person commits an offence if the person provides any service specified in subsection (4) with the intention [our emphasis] of giving a student an unfair advantage over other students". The amendment to UK law as proposed by Lord Storey of Liverpool (Newton and Draper, 2017a, b) had very similar wording. In rebutting that proposal, Baroness Goldie stated to the UK House of Lords;

"it may be difficult to prove that a provider intended to give an unfair advantage, or that an advertiser knew that an unfair advantage would be bestowed' 
In earlier work (Draper, Ibezim and Newton 2017) we specifically identified this problem with requiring 'intent'. Commercial providers of contract cheating services protect themselves in their terms and conditions by, in essence, ensuring that intent remains with the student, as we discuss below under 'unintended consequences'. This is in contrast with the advertising using by the companies, as described above.

\section{Amending the current legal situation to make it fit for purpose - A proposed law against contract cheating which applies the principles of strict liability}

Legal Basics; Strict Liability. An offence of strict liability is committed when the facts support the commission of offence, without the need to prove intent or intention on the part of the offender. For example, driving a vehicle, on a public highway, without insurance cover. In such a case the state of mind of the driver is irrelevant; that the driver forgot to renew insurance cover is not relevant to the commission of an offence. Strict liability offences are often used in matters of significant public interest. Supporting the quality and integrity of a Higher Education award is arguably a matter of significant public interest, for reasons outlined above.

If a strict liability offence was enacted against contract cheating, then the person supplying the assignment, be they an 'essay mill' or individual, would be liable simply for supplying an assignment, unless they could prove they had taken all reasonable steps to ensure that a student would not submit the assignment to a Higher Education provider as their own work (i.e. a defence of due diligence). Disclaimers provided in 'Terms and Conditions' of essay mills would, by themselves, not be considered 'reasonable steps' as it is well established that these are unlikely to be read, and they contradict the offering of the companies re: 'plagiarism-free' guarantees, having work provided to a specific grade standard, draft version of the assignment, etc. (Draper, Ibezim and Newton 2017).

Thus we propose a redrafted clause, adapted from the New Zealand law, as shown in Table 1. In keeping with the established principle of strict liability, Paragraph 5 of the proposed offence in Table 1 reverses the burden of proof with regard to intent; it is for the accused to demonstrate that they are innocent and not for the prosecuting authority to prove intent (which is challenging and often a barrier to prosecution). This principle is found in most common-law countries (for example (Australian Law Reform Commission 2016; Law Reform Commission of Canada 1974)), and thus could be used in multiple jurisdictions. The penalty for the offence would need to be both proportionate and act as a deterrent, as discussed above.

Another approach to tackling the issue of 'intent', discussed previously (Newton and Lang 2016) comes from a principle used by some older laws in the USA whereby prosecution may be successfully brought on the basis of what the parties ought reasonably to have known. Thus if a custom-essay writing website has a disclaimer that the work is to be used for reference purposes only, but then advertises specific grades, a plagiarism-free guarantee, the availability of draft versions etc., then it would be reasonable to infer that they (and the student) are aware that the work is to be used as if it were the student's own. However this approach still requires the prosecuting authority to establish this point beyond reasonable doubt before an offence is committed and potentially remains a barrier to prosecution. 
In the remainder of this article, we will 'test' our proposal against many of the other legal and cultural issues associated with contract cheating, issues which have affected earlier attempts to take a legal approach to tackling contract cheating. We will contrast the contents of Table 1 with existing laws.

\section{A definition of 'contract cheating'}

An additional problem was identified in the aforementioned January 2017 debate in the UK House of Lords, where a proposed amendment to UK law tackling contract cheating (based on the New Zealand law) was considered. The problem identified was; how to define a law which specifically targets contract cheating, while protecting legitimate services. Baroness Goldie again;

"...there is a risk of capturing legitimate services such as study guides under the same umbrella definition. What is an "unfair advantage"? On one view, a student who is able to afford a tutor when others cannot obtains an unfair advantage. That is surely not what this amendment is trying to catch. But can we be sure that it does not, and where do we draw the line instead? These are not things that can, or should, be rushed when the result is a criminal record."

Many definitions of contract cheating exist in the academic literature, and we began this article with one of our own. Commonly cited are those put forward by Clarke and Lancaster and which are used by this special edition of the International Journal of Educational Integrity (https://edintegrity.springeropen.com/cche). The IJEI website states

“The term 'contract cheating' was first coined by Clarke and Lancaster (2006).

Contract cheating occurs when students employ or use a third party to undertake

their assessed work for them, and these third parties may include:

- essay writing services;

- friends, family or other students;

- private tutors;

- copyediting services;

- agency websites or 'reverse classifieds' (Lancaster E Clarke, 2016: 639)"

The bold is taken from the website and the citations used above are contained within (Lancaster and Clarke 2016).

This definition is beset by the problems articulated by Baroness Goldie and which have exercised scholars in academic integrity for many years; at what point do these and other services cross the line from 'legitimate' to 'cheating' (contract or otherwise). How does one distinguish between proofreading, private tutoring etc. and contract cheating. In essence, how does one define 'undertake'?

We address this in our definition at the beginning of this article, and incorporate it into the legal proposal we make in Table 1. Paragraph 1 of the proposal states; "a person commits an offence only if the assignment or work could not otherwise be reasonably considered to be that of the student concerned". This draws upon the well-established principle of defining plagiarism; whose work is it? This principle of a test of reasonableness is one that 
courts are often required to utilise, and in the case of contract cheating would protect those who provide legitimate study aids and guidance.

\section{Whose law is it anyway?}

As a standalone law, the proposal in Table 1 would not always address the international nature of contract cheating; as discussed above, an episode of contract cheating can include just three actors (student, university, third party), but may include many more; a company, regulated by a government, hosted on a website, with advertisers and advertising, a bidding system with multiple writers etc. Every single one of these actors could be in a different country. Generally, an offence will only be prosecuted in the jurisdiction in which the offence takes place, unless specific laws enable extra-territorial jurisdiction or co-operation. ${ }^{8}$ Legal approaches to contract cheating need to consider how to address this international aspect.

Having suggested a new strict liability criminal offence to tackle contract cheating (Table 1) we need also to address issues of territoriality and jurisdiction in terms of enforcement. There are principles we can utilise from current UK laws regarding fraud and bribery, both of which impose extraterritorial jurisdiction, i.e. elements of the laws apply outside the UK.

Legal Basics; Extraterritoriality. We will use the UK Bribery Act 2010 to explain how 'extraterritoriality' works, and how the principles might be applied to our proposed offence against contract cheating as shown in Table 1 . We are not proposing to use the Bribery Act itself to prosecute contract cheating, but rather to take the principles of extraterritoriality as defined by the Act, and apply them to laws targeting contract cheating.

The UK Bribery Act 2010 creates four main offences. The most important offence for our purposes is that contained in section 7 of the Act - an offence of failure by a commercial organisation to prevent a bribe being paid to obtain or retain business or a business advantage. Its territorial scope is extensive as it applies to any relevant commercial organisation defined as a body incorporated under the law of the United Kingdom (or United Kingdom registered partnership) and any overseas entity that carries on a business or part of a business in the United Kingdom [our emphasis].

Thus an important principle is that a foreign company which carries on any part of its business in the UK can be prosecuted for failure to prevent bribery even where the bribery takes place wholly outside the UK and the benefit or advantage to the company is intended to accrue outside the UK, and regardless of whether carried out by UK nationals, or by UK-registered companies. ${ }^{9}$ As long as some part of the business takes place in the UK, the company can be prosecuted.

Furthermore, once it is established that a commercial organisation carries on a business or part of a business in the UK, if an "associated person" (for example, an employee, agent, or subsidiary) bribes another person to the benefit of the organisation, the organisation may be guilty of the offence unless it can demonstrate that it had adequate procedures in place to prevent such conduct. Importantly, it 
does not matter if the "associated person" has no connection with the UK or that the offence took place abroad. This means that, theoretically, a parent company incorporated in Country A whose agent based in Country B bribes an official in Country $C$ for the parent's benefit, could be prosecuted in the UK because its subsidiary is located in London, regardless of the fact that the subsidiary is uninvolved in the offence.

We summarise, in Table 2, how these principles could be applied to contract cheating. Where contract cheating results in an assignment submitted by a student to a Higher Education provider in the UK, all of the other actors involved in that contract cheating could be liable, under UK law, for the offence, even if none of them were based in the UK and none of the work required to generate the assignment took place in the UK. This could include the writer, the agent, the company, and the website where the transaction took place (e.g. a freelancing-type auction website), and could apply equally if any one of the actors was based in the UK (e.g. a UK-based writer prepares an assignment for a student at an overseas institution). Additionally where contract cheating results in an assignment submitted to a Higher Education provider in another country, if any of the actors involved in that contract cheating were based in the UK, then they could be prosecuted under UK law.

Similar principles are found elsewhere in international law. For example, Canadian anti-corruption laws have principles of extraterritoriality that are similar to those found in the UK Bribery Act. ${ }^{10}$ In the United States, the Foreign Corrupt Practices Act 1977, ${ }^{11}$ has a similar goal to the Bribery Act 2010 and, in its extraterritorial reach, a similar impact although is perhaps narrower in its scope. However both represent a wider international trend of addressing anti-corruption through legislative responses and extending liability and enforcement beyond national borders.

Further principles of 'extraterritoriality' can be found in the regulations governing advertising. The Advertising Standards Authority (ASA) is the UK's independent selfregulator of advertising across all media. Its work includes acting on complaints and proactively checking the media to take action against misleading, harmful or offensive advertisements that contravene its Advertising Codes. The Codes cover advertising and marketing communications and, broadly speaking, advertising is required to be legal, decent, honest and truthful. If a complaint about an advertisement is upheld, the advertiser must withdraw or amend the advertisement and not use the advertising approach again. ${ }^{12}$ The ASA is a founding member of the European Advertising Standards Alliance (EASA). EASA's role is to encourage high standards in advertisements through effective self-regulation, while being conscious of national differences of cultural, legal and commercial practice. A Cross-Border Complaints $(\mathrm{CBC})$ system was established immediately after the setting up the EASA in 1992. In a nutshell, the CBC system is an agreement by which all self-regulatory organisations that are a member of EASA have

Table 2 Applying 'extraterritoriality' to a new "Offence to provide or advertise cheating services"

The concept of 'extraterritoriality' defined in the UK Bribery Act 2010 could be employed in a new criminal offence outlawing the activity of essay mill companies (Table 1), and the concept of associated persons could be employed against employees of the company and agents/writers engaged by the company in the essay mill industry. This would mean that, if (for example) a student submitted a purchased assignment to a UK University, the company that sold the assignment, and the writers, and the advertisers, could all be subject to prosecution even if they were not based in the UK. 
agreed to handle cross-border complaints under the same conditions as national complaints. Two types of complaints fall under the term 'Cross-Border Complaint': First, it may be a complaint from a person in one country about an advertisement that has appeared in that country, but was carried in media broadcast from another country. Second, it may be a complaint made by an individual resident of one country who is visiting another country in which the advert appears. In either case that person would send their complaint to the self-regulatory organisation in their home country (e.g. the ASA for a UK resident) who would then forward it to its counterpart in the other country. Alternately, the complaint can be sent directly to EASA who will then forward the complaint to the correct body. This applies to complaints about the advertising of contract cheating services.

Of course, it is one thing to identify laws that can be used across international borders, but it is quite another to actually enforce them. However there are obviously precedents with international enforcement of laws regarding (for example) drug trafficking and immigration, plus the current position is that many companies operate in plain sight in countries where, should laws be enacted, they could be dissuaded from operating (e.g. Australia UK, USA, Canada). The enactment of laws, coupled with successful prosecution of companies currently operating in those countries, would, in our academic opinion, be a significant improvement on the current position.

\section{Unintended consequences?}

We have identified a new law (Table 1) that could be used to mount a legal challenge to contract cheating, in particular commercial contract cheating services. We have also highlighted principles of extraterritoriality that could be used to address the international nature of contract cheating (Table 2), along with further principles regulating international advertising. Any change to the laws governing Higher Education would of course require that the regulations of education providers were reviewed to ensure that the complied with new laws. However, there are a number of additional factors that need to be considered when developing a legal approach to contract cheating of the type identified in Tables 1 and 2, and we work them through in this section, also showing how existing laws do not address these issues.

\section{Criminalisation of academic activities}

Clearly, if are committed on University premises (e.g. assault or theft) then these may be dealt with through legal means. But in the case of contract cheating, this could mean the criminalisation of a behaviour that has traditionally been addressed largely through academic means and happens largely within the context of academic study.

In a recent report the United Kingdom regulator of Higher Education, the Quality Assurance Agency (QAA), when considering the use of existing laws to tackle contract cheating, stated that fraud law was "the nearest applicable legislation". In a recent paper (Draper, Ibezim and Newton, 2017) we then considered whether the activities of some UK-registered essay writing companies would meet this definition. In summary, our academic opinion was that the companies would not obviously be considered to be committing fraud, under existing laws, due to the terms and conditions they deploy. 
However, we identified another issue with fraud law, relevant to contract cheating and academic integrity generally. Consider the wording of the 2006 UK Fraud Act itself, specifically the first two paragraphs of Section 2 (Fraud by false representation) which is perhaps the most relevant;

1) A person is in breach of this section if he-

(a) dishonestly makes a false representation, and

(b)intends, by making the representation-

(i) to make a gain for himself or another, or

(ii) to cause loss to another or to expose another to a risk of loss.

2) A representation is false if-

(a) it is untrue or misleading, and

(b)the person making it knows that it is, or might be, untrue or misleading.

Although we considered it unlikely that commercial contract cheating services would be liable under existing UK fraud law, a different picture, one that will be uncomfortable for many, emerges when one re-reads the definition above and considers the behaviour of a student who purchases an assignment and submits it, for academic credit, as if it were their own work.

There are many 'gains' (some perhaps remote in a legal sense) to be had, for a student who successfully passes an assignment; the graduate achieves academic credit and a particular level of award and is more likely to be employable, they may avoid any additional tuition fees and living expenses incurred to retake assignments or periods of study, they might avoid being expelled from their University which might otherwise leave them having to repay tuition debts but with no degree. There are also, potentially, 'losses' that are incurred by a Higher Education provider when a student engages in contract cheating, e.g. staff time spent investigating the case, setting and marking the assessment, etc. Thus if we consider a student who purchases an essay from a commercial service and then submits it as their own work, there is an argument that this fits a definition of fraud subject to a finding of dishonesty being made. This is, in essence, the message to students from the terms and conditions of the companies themselves; 'we provide you with a product, but if you choose to misuse it, that is your responsibility'.

Pursuing a legal approach to contract cheating using existing laws therefore seems to require a consideration of the prosecution of students. The legal system has shown a reluctance to become involved when students commit plagiarism. A recent review conducted by the UK regulator, the Quality Assurance Agency, stated "Case law appears to indicate a reluctance on the part of the courts to be involved in cases involving plagiarism, deeming this to be a matter for academic judgement that falls outside the competence of the court (Hines v Birkbeck College [1985] 3 All ER 15)" (QAA 2016). There are examples of this from the legal literature surrounding contract cheating. As far back as 1972, in a case involving the prosecution of a North Carolina (USA) 'term paper' company, the prosecuting solicitor apparently stated "We were not interested in the prosecution of the students and told them we would not disclose their names". He is reported to have gone on to have assured the students he "would make sure their schools did not find out about the dealings with the term paper service" (quoted in Duke Law Journal 1974). 
However, the evolving nature of the formal relationship between a student and their University means that legal considerations are likely to become more important generally, not just with regard to contract cheating.

This is mainly because as noted above in addition to standard contract law, students are likely to have rights as a 'consumer' in their relationship with Universities. ${ }^{13}$ In simple terms, if University regulations pertaining to contract cheating are not compliant with consumer and contract law, then HE providers may find that decisions they make on individual cases may later be overturned in the courts, and the University subject to a counter-claim by the student e.g. to recover lost fees, opportunities for earnings etc.

In addition a University should carefully consider whether to refer a student for prosecution in relation to fraud or dishonesty unless it is satisfied that the regulations have not caused confusion in the mind of a student as to the likely consequences of their actions unless the actions of the student are obviously dishonest. Should all academic misconduct regulations now carry a warning that certain types of misconduct may be susceptible to criminal prosecution in addition to University sanctions?

There are legal precedents where Universities have taken action to refer academic misconduct to the police for investigation. An example from Australia is the 'Mytutor' case at RMIT University, Melbourne, following the introduction of new plagiarismmanagement procedures in 2001 (Zobel 2004). York University (UK) referred cases of impersonation fraud to the police, wherein a fake ID card was used by someone outside the university to take exams for an economics student between January 2006 to May 2007. Both the contractor and the student were charged with multiple counts of fraud-related offences, including possessing an ID card for the use of fraud, possessing a false ID card for use in fraud, falsely claiming to be another person, and using a false ID card to defraud the University. The contractor was also accused of possessing $£ 4000$ in criminal assets, believed to be the fees paid to him by the student. In mitigation the men claimed that they had not realised that they were committing a criminal offence and pleaded guilty to a single charge of conspiring to defraud the University of York by obtaining a fake ID card in the name of the student, and allowing the contractor to sit the exams. They pleaded not guilty to all the other charges.

In summarising the case, the judge stated: "The fact you have admitted the offence goes in your favour, but this is an unusual and serious case of dishonesty" and went onto say that: "The court simply does not know how serious a problem examination fraud of this kind may be. If it's widespread of course it erodes the confidence the public can have in academic degrees. This conduct, and your conduct in particular, must be deeply offensive to the thousands of diligent students who do work hard." (Caulfield 2008).

Thus there is a precedent for pursuing student academic misconduct through legal means, albeit based on a small sample. However these cases raise further concerns regarding a legal approach to contract cheating based on existing laws. The most obvious are the simple issues of workload and timescale, as referred to in the detailed accounts cited above, for example the RMIT case apparently took two years to resolve and a significant amount of academic staff time in preparation for and attendance at court 
hearings (Zobel 2004). In the York case, the defendants claimed they did not know they were committing a criminal offence. Any change to the legal status of contract cheating will require extensive additional education if it is to be effective, and provision for additional staff time to prepare for and attend court hearings.

\section{Is the 'contract' required}

Is it necessary for the student to have engaged in contract cheating in order to make a fraudulent gain? Re-reading the UK Fraud Act as reported above, it seems likely that 'regular' copy-and-paste plagiarism could result in the same gain, via 'fraudulent' means. Thus where do we draw the line between plagiarism and fraud? Would there even be a line? Are students already committing 'fraud' - should HE providers be reporting this to the police? Given the apparently high frequency with which some students engage in 'ordinary' plagiarism; almost 40\% according to some studies (McCabe 2016), and the poor understanding that students have of these concepts, particularly when they first enter higher education (Newton 2015), do we risk criminalising millions of students? Assuming that this would be an undesirable outcome, any use of legislation to address contract cheating would require careful enacting, or even new laws, to avoid it - this could even apply to the proposed law in Table 1, as we explore further below.

\section{Other considerations}

In any case where a legal approach is taken to contract cheating, the person identifying the 'crime' is most likely to be one identified in Fig. 1, for example another student, or a member of University staff, or a parent/guardian. The expectation then would be that, when uncovering the 'crime', this person, now a possible witness to a crime, should call the police and hand over assignments, originality reports, emails etc. There is an argument that this may actually reduce the likelihood of contract cheating being reported, although this could be countered by making it a 'duty to report', something that would apply anyway to teachers and students on many professional qualifications (medicine, nursing, law etc). In 2012 Thomas and Bruin surveyed academics in HE to determine what the barriers were to action on academic misconduct (Thomas and Bruin 2014). They identified four key barriers, the first of which was the psychological discomfort and cost associated with reporting and investigating. If the institution wishes to address student academic dishonesty, such dishonesty must be identified, reported, and dealt with. Accordingly, the psychological discomfort of and costs to faculty that pose a barrier to reporting need to be recognised. The facet of psychological discomfort may be difficult to address as, at least in part, it may be due to a personality disposition related to conflict avoidance; in the survey reported by Tomas and Bruin, strongest agreement was with the statement "Fear of developing a negative reputation among students prevents lecturers from dealing with student academic dishonesty", while other questions with strong agreement related to workload. Both these barriers seem likely to increase if contract cheating moves from the realm of academic misconduct to criminal behaviour.

The proposals made in Tables 1 and 2 would go a long way to addressing many of these unintended consequences. They would directly target specific actors identified in red in Fig. 1, and would therefore protect the relationships between other actors (blue), and not 
add deterrents associated with additional workloads. They would allow for a positive, academic-integrity focused approach to be continued within Higher Education institutions, while targeting external agencies that offer or support contract cheating services.

Some complications may however arise where one of the other actors identified in blue in Fig. 1 is, themselves, also a provider of contract cheating services. Indeed, preliminary findings from a large research project in Australia indicate that students are more likely to outsource assignments to friends or family than they are to commercial services. ${ }^{14}$ We propose that the laws be used primarily to target large-scale commercial organisations, but the spirit of the law could also have a deterrent effect on outsourcing to friends and family. It is even possible that the proposal in Table 1 could be amended to exclude prosecution of individual students enrolled at a Higher Education institution, directing them instead to be pursued through traditional academic means, although in our view this could create a loophole for commercial services to exploit.

\section{Would it work}

Would the new law proposed in Table 1 actually work. On the face of it, defining the meaning of 'works' in this context seems straightforward; if a legal approach had been successful, this would be measured as a reduction in the incidence of contract cheating. However, the data are not available to answer this question, and even if they were, it does not address some wider issues associated with the problem.

\section{Metrics}

One of the most problematic aspects of contract cheating, and yet one of the most appealing for those who use the services, is that it is hard to detect and the assignments usually pass (Lines 2016), although it is slightly easier to detect when markers are told that some assignments in a sample have been purchased (Dawson and SutherlandSmith 2017). Even if a marker raises a suspicion, this alone is rarely sufficient to conclusively demonstrate that contract cheating has occurred. This means that traditional measures of problem behaviours, such as the rate at which people are caught engaging in it, would be of little value. Thus we do not have a good objective measure of how big the problem is, and no baseline against which to evaluate any intervention. There are subjective and indirect measures, the simplest of which is simply to ask students whether they have ever used these services. Many studies have attempted to answer this question and published results vary from zero (Hart and Morgan 2010; Dereczyk et al. 2010) to over $20 \%$ (Hosny and Fatima 2014) and most studies use fairly small samples. Thus we would be attempting to measure a change in noisy and limited dataset. Even then, if there were a change in the numbers of student's self-report contract cheating, it would be difficult to determine whether that change was real, or whether the newly criminal status of the behaviour meant that students were simply less likely to say they had engaged in it. This also, potentially, creates political problems for policy makers as it would be difficult to generate objective evidence of the success of a legal approach in terms of a reduction in the incidence of contract cheating. This could be offset by the successful prosecution of commercial contract cheating providers, particularly where, as in the case of Assignment $4 \mathrm{U}$, the company allegedly generated considerable revenue (itself a metric) from contract cheating. 


\section{Demand vs supply}

It is difficult to see how criminalisation would address of the causes of contract cheating. There is obviously a demand for contract cheating services, or there would not be hundreds of websites offering them. Many causes have been proposed for this demand, similar to the causes of academic misconduct generally (not just contract cheating); a motivation to get a better grade; poor time management; personal/cultural beliefs, e.g. that plagiarism is not wrong; negative attitudes towards authority/tutors; availability of opportunity (e.g. it is easy to do); commercialisation of universities with a focus on recruitment and retention which conflicts with sanctioning or even removing students for plagiarism (Park 2003; Brimble 2015). Many of these motivators, which are in essence demand-led market forces, would not be directly diminished by criminalisation of the supply although new specific offences in relation to the supply side of contract cheating could be drawn to the attention of students which might act as a deterrent to commissioning.

\section{Other legal considerations}

In fig. 1 above we note that the core relationship between a student and essay writer and a student and University is governed primarily (but not exclusively) by the (Civil) law of contract. Although in this paper we focus primarily on the role that the criminal law could play in preventing contracting cheating we acknowledge that the civil law through breach of contact claims may also have a role. However it is unlikely that students would want to publicly pursue claims against essay mills in the courts if the student does not receive what they contracted for and a University is unlikely (for reasons noted below) to pursue a contractual claim against a student for loss suffered in marking and grading a submission that was not entirely the work of a student and for loss in respect of the time and resources spent in subsequently pursuing a student for academic misconduct. Nevertheless there are potential approaches to tackling contract cheating through civil law, and potential complications of so doing. These are beyond the scope of this paper and will inform future research.

\section{Summary}

There are a considerable number of challenges to be overcome if the international HE sector and governments wish to pursue a legal approach to tackling contract cheating; new laws would likely be required, that effectively address the issue of 'intent' to (help) cheat and consideration would need to be made as to how these would work across international borders. However, as we have shown above, there is legal precedent to show that a new law could be introduced, or existing laws could be modified simply, using the principle of strict liability (Table 1), and pursued across borders (Table 2).

However even if these could be overcome, it is not clear that a legal approach would be effective, or that we would even know, or that it would address the demand for contract cheating services.

Nevertheless we believe that a legal approach should be seriously considered as it would satisfy the two main criteria for pursuing a prosecution; evidence would be available, and it would be, on balance, in the public interest to do so. Contract cheating, by definition and nature, is fundamentally wrong and poses a potential threat to standards 
in higher education and thus, by extension, public safety. We have offered practical suggestions for pursuing a legal approach.

\section{Endnotes}

${ }^{1}$ https://www.unodc.org/documents/justice-and-prison-reform/14-07304_ebook.pdf pp8-9 (accessed 15.6.17)

${ }^{2}$ http://news.bbc.co.uk/1/hi/education/6680457.stm

${ }^{3}$ Commissioner of Police v Li [2014] NZHC 479

${ }^{4}$ Tesco Supermarkets Ltd. v Nattrass [1972] AC 153

${ }^{5}$ http://www.cps.gov.uk/legal/a_to_c/corporate_prosecutions

${ }^{6}$ (Hansard UK) HL Deb 25 January 2017, vol 778 col. 776

${ }^{7}$ (Hansard UK) HL Deb 25 January 2017, vol 778 col. 776

${ }^{8}$ http://www.cps.gov.uk/legal/h_to_k/jurisdiction/ accessed 22/5/17

${ }^{9}$ https://www.justice.gov.uk/downloads/legislation/bribery-act-2010-guidance.pdf

Accessed 22.5.17

${ }^{10}$ R. v. Libman, [1985]2 S.C.R. 178

${ }^{11}$ https://www.justice.gov/criminal-fraud/foreign-corrupt-practices-act

${ }^{12}$ The role of the Advertising Standards Authority, House of Commons Briefing Paper Number CPB 06130, 2016

${ }^{13}$ In (Turner \& Co (GB) Ltd. v Abi [2010] EWHC 2078, the courts referred to the distinction between a 'trader' and a 'consumer' as depending on whether the person was acting primarily for his own 'family or personal needs'.

${ }^{14}$ https://cheatingandassessment.edu.au/resources/

\section{Acknowledgements}

The authors would like to acknowledge the contributions of the two anonymous peer reviewers for their thoughtful consideration of this manuscript.

Authors' contributions

Both authors contributed equally to this work and both authors read and approved the final manuscript.

Competing interests

The authors declare that they have no competing interests.

\section{Publisher's Note}

Springer Nature remains neutral with regard to jurisdictional claims in published maps and institutional affiliations.

\section{Author details}

${ }_{1}^{1}$ College of Law, Swansea University, Singleton Park Campus, Swansea, UK. ${ }^{2}$ Swansea University Medical School, Swansea University, Singleton Park Campus, Swansea, UK.

Received: 14 August 2017 Accepted: 12 November 2017

Published online: 29 November 2017

\section{References}

Australian Law Reform Commission, Web. 2016. Traditional Rights and Freedoms-Encroachments by Commonwealth Laws (ALRC Report 129)'. https://www.alrc.gov.au/publications/freedoms-alrc129

Bartlett T (2009) Cheating goes global as essay Mills multiply. Chron High Educ 55(28)

Bomford A (2016) The man who helps students to cheat. BBC News 2016 http://www.bbc.co.uk/news/magazine36276324

Brimble M (2015) Why Students Cheat. An Exploration of the Motivators of Student Academic Dishonesty in Higher Education. In: Bretag TA (ed) Handbook of Academic Integrity. Springer, Singapore, pp 1-14 https://doi.org/10. 1007/978-981-287-079-7_58-1

Caulfield, Amy. 2008. "Talented" Asperger's Man Escapes Jail for Exam Fraud'. The Independent, 2008. http://www. independent.co.uk/news/uk/crime/talented-aspergers-man-escapes-jail-for-exam-fraud-789991.html

Dawson, Sutherland-Smith (2017) Can markers detect contract cheating? Results from a pilot study: Assessment \& Evaluation in higher education: Vol 0, no 0. In: Assessment and Evaluation in Higher Education online early http:// srhe.tandfonline.com/doi/abs/10.1080/02602938.2017.1336746 
Dereczyk A, Bozimowski G, Thiel L, Higgins R (2010) 'Physician Assistant Students' Attitudes and Behaviors Toward... : The Journal of Physician Assistant Education'. J Physician Assist Educ 21(1):10-17

Dickerson D (2007) Facilitated plagiarism: the Saga of term-paper Mills and the failure of legislation and litigation to control them. Villanova Law Review 52:21

Draper MJ, Ibezim V, Newton PM (2017) 'Are Essay Mills Committing Fraud? An Analysis of Their Behaviours vs the 2006 Fraud Act (UK)'. International Journal for Educational Integrity 13(1): 3. doi:10.1007/s40979-017-0014-5

Duke Law Journal (1974) Term paper companies and the constitution. Duke Law Journal 1973(6):1275-1317

Hart L, Morgan L (2010) Academic integrity in an online registered nurse to baccalaureate in nursing program. J Contin Educ Nurs 41(11):489-505

Henry, Robin, Cal Flyn, and Katie Glass. 2014. '£630 and I'll Put You on the Way to a First", 2014. http://www. thesundaytimes.co.uk/sto/news/article1422913.ece

Hosny M, Fatima S (2014) Attitude of students towards cheating and plagiarism: university case study. J Appl Sci 14(8): 748-757 https://doi.org/10.3923/jas.2014.748.757

Irish Legal News. 2017. "'Essay Mills" to be subject to prosecution under new law'. Irish legal news. 15 May 2017. http:// www.irishlegal.com/7279/essay-mills-to-be-subject-to-prosecution-under-new-law/

Lancaster T, Clarke R (2016) Contract cheating: the outsourcing of assessed student work. In: Bretag T (ed) Handbook of Academic Integrity. Springer, Singapore, pp 639-654 https://doi.org/10.1007/978-981-287-098-8_17

Law Reform Commission of Canada (1974) Criminal law, strict liability. In: Information Canada

Lines L (2016) Ghostwriters guaranteeing grades? The quality of online ghostwriting services available to tertiary students in Australia: teaching in higher education: Vol 21, no 8. Teach High Educ 12(8). http://srhe.tandfonline. com/doi/abs/10.1080/13562517.2016.1198759

McCabe D (2016) Cheating and honor: lessons from a long-term research project. In: Bretag T (ed) Handbook of Academic Integrity. Springer, Singapore, pp 187-198 https://doi.org/10.1007/978-981-287-098-8_35

Newton P (2015) 'Academic Integrity: A Quantitative Study of Confidence and Understanding in Students at the Start of Their Higher Education'. Assessment \& Evaluation in Higher Education 0 (0): 1-16. doi:10.1080/02602938.2015. 1024199

Newton P, Lang C (2016) 'Custom Essay Writers, Freelancers, and Other Paid Third Parties'. In Handbook of Academic Integrity, edited by Tracey Bretag, 249-71. Springer Singapore. doi:10.1007/978-981-287-098-8_38

Newton PM, Draper MJ (2017a) 'University Students Are Buying Assignments - What Could, or Should, Be Done about It?' Impact of Social Sciences. February 28. http://blogs.lse.ac.uk/impactofsocialsciences/2017/02/28/universitystudents-are-buying-assignments-whatcould-or-should-be-done-about-it/

Newton PM, Draper (2017b) 'A New Law Is Needed to Tackle Contract Cheating in the UK'. BioMed Central Blog. January 25. https://blogs.biomedcentral.com/bmcblog/2017/01/25/a-new-law-is-needed-totackle-contract-cheatingin-the-uk

Owings S, Nelson J (2014) The essay industry. Mountain Plains Journal of Business and Economics, General Research 15

Park C. (2003) In other (People's) words: plagiarism by university students-literature and lessons. Assessment \& Evaluation in Higher Education 28(5):471-488 https://doi.org/10.1080/02602930301677

QAA. 2016. 'Plagiarism in Higher Education - Custom Essay Writing Services: An Exploration and next Steps for the UK Higher Education Sector'. http://www.qaa.ac.uk/publications/information-and-guidance/publication?PublD=3107\#. V9cAhq2GNsg

Thomas A, De Bruin GP (2014) Student academic dishonesty: what do academics think and do, and what are the barriers to action? African J Bus Ethics 6(1). https://doi.org/10.15249/6-1-8

Usborne S (2017) Essays for sale: the booming online industry in writing academic work to order. In: The Guardian, 4 march 2017, sec. Education https:/www.theguardian.com/education/2017/mar/04/essays-for-sale-the-boomingonline-industry-in-writing-academic-work-to-order

Zobel, Justin. 2004. "Uni Cheats Racket": A Case Study in Plagiarism Investigation'. In Proceedings of the Sixth Australasian Conference on Computing Education - Volume 30, 357-365. ACE '04. Darlinghurst, Australia, Australia: Australian Computer Society, Inc. http://dl.acm.org/citation.cfm?id=979968.980016

\section{Submit your manuscript to a SpringerOpen ${ }^{\circ}$ journal and benefit from:}

- Convenient online submission

- Rigorous peer review

Open access: articles freely available online

High visibility within the field

- Retaining the copyright to your article

Submit your next manuscript at $\gg$ springeropen.com 